\title{
Protection of pancreatic INS-1 $\beta$-cells from glucose- and fructose-induced cell death by inhibiting mitochondrial permeability transition with cyclosporin A or metformin
}

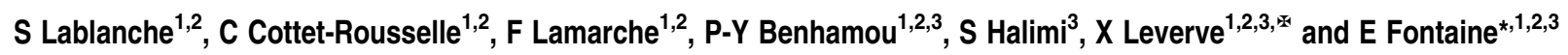

Hyperglycemia is detrimental to $\beta$-cell viability, playing a major role in the progression of $\beta$-cell loss in diabetes mellitus. The permeability transition pore (PTP) is a mitochondrial channel involved in cell death. Recent evidence suggests that PTP inhibitors prevent hyperglycemia-induced cell death in human endothelial cells. In this work, we have examined the involvement of PTP opening in INS-1 cell death induced by high levels of glucose or fructose. PTP regulation was studied by measuring the calcium retention capacity in permeabilized INS-1 cells and by confocal microscopy in intact INS-1 cells. Cell death was analyzed by flow cytometry. We first reported that metformin and cyclosporin A (CsA) prevented $\mathrm{Ca}^{2+}$-induced PTP opening in permeabilized and intact INS-1 cells. We then showed that incubation of INS-1 cells in the presence of $30 \mathrm{mM}$ glucose or $2.5 \mathrm{mM}$ fructose induced PTP opening and led to cell death. As both metformin and CsA prevented glucose- and fructose- induced PTP opening, and hampered glucose- and fructose- induced cell death, we conclude that PTP opening is involved in high glucoseand high fructose- induced INS-1 cell death. We therefore suggest that preventing PTP opening might be a new approach to preserve $\beta$-cell viability.

Cell Death and Disease (2011) 2, e134; doi:10.1038/cddis.2011.15; published online 24 March 2011

Subject Category: Internal medicine

Under physiological condition, glucose serum concentration fluctuates between 3.6 and $7 \mathrm{mM},{ }^{1}$ whereas fructose serum concentration remains below the limit of detection by enzymatic methods. ${ }^{2}$ Under diabetic conditions, fructose serum concentration increases, most probably because glucose is converted into fructose via the polyol pathway. ${ }^{3,4}$ Moreover, the splanchnic territory is physiologically exposed to high concentrations of glucose and fructose during the postprandial period. ${ }^{5}$ Therefore, $\beta$-cells can face hyperglycemia or hyperfructosemia in type 2 diabetes or when pancreatic islets are transplanted into the splanchnic territory.

The permeability transition pore (PTP) is a $\mathrm{Ca}^{2+}$-sensitive mitochondrial inner membrane channel. ${ }^{6,7}$ Normally closed in order to allow ATP synthesis, the PTP leads to mitochondrial depolarization and cell death after extended opening. ${ }^{8} \mathrm{Ca}^{2+}$ is the single most important factor for PTP opening. The amount of $\mathrm{Ca}^{2+}$ required to open the pore varies according to a number of factors. 'PTP-inhibitors' and so-called 'PTPinducers' refer to factors that increase and decrease the amount of $\mathrm{Ca}^{2+}$ required to induce PTP opening. ${ }^{9}$ Cyclosporin $A(C s A)$ is the reference PTP inhibitor, whereas oxidative stress is well recognized as favoring PTP opening. ${ }^{6}$
In several cell types, direct or indirect inhibition of respiratory chain complex 1 inhibits PTP opening. ${ }^{10-12}$ In such cells, the antidiabetic drug metformin inhibits PTP opening via a mild inhibition of complex $1 .^{11}$

Chronic exposure to elevated glucose or fructose concentrations impairs $\beta$-cells survival ${ }^{13,14}$ by a mechanism that may involve oxidative stress. ${ }^{13,15,16}$ Hyperglycemia-induced oxidative stress has been shown to induce mitochondrial permeability transition and subsequent cell death in human endothelial cells. ${ }^{11}$ Concerning pancreatic-derived cells, CsA has been shown to inhibit $\mathrm{Ca}^{2+}$-induced PTP opening in permeabilized INS-1 and MIN-6 cells. ${ }^{17}$ It has been proposed that cytokine-induced apoptosis may be due to PTP opening in pancreatic RINm5F cells ${ }^{18}$ whereas CsA has been reported to prevent PK11195-induced cell death in isolated human pancreatic islets. ${ }^{19}$ Finally, it has recently been shown that CsA protects MIN-6 cells against Pdx1 insufficiency-induced cell death, although genetic ablation of the endogenous PTP-inducers cyclophilin D prevents diabetes in $\mathrm{Pdx} 1^{+/-}$ mice. $^{20}$ Whether metformin regulates PTP opening in $\beta$-cells and whether hyperglycemia or hyperfructosemia induces PTP opening in pancreatic-derived cells has not been studied yet.

\footnotetext{
${ }^{1}$ Inserm, U1055, Grenoble F-38041, France; ${ }^{2}$ Joseph Fourier University, Grenoble F-38041, France and ${ }^{3}$ Grenoble University Hospital, Grenoble F-38043, France ${ }^{*}$ Corresponding author: E Fontaine, INSERM U1055 - LBFA, Joseph Fourier University, BP 53, Grenoble Cedex 38041, France. Tel: + 33476 635601; Fax: + 33476 514218; E-mail: eric.fontaine@ ujf-grenoble.fr

"Professor X Leverve (1950-2010), in memoriam.

Keywords: permeability transition; glucotoxicity; fructose; INS-1; cyclosporin; metformin

Abbreviations: PTP, permeability transition pore; CsA, cyclosporin A; CRC, $\mathrm{Ca}^{2+}$ retention capacity; TMRM, tetramethylrhodamine methyl ester

Received 27.1.11; revised 09.2.11; accepted 10.2.11; Edited by M Federici
} 


\section{Results}

CsA and metformin inhibit PTP opening in permeabilized INS-1 cells. The $\mathrm{Ca}^{2+}$ retention capacity (CRC) represents the minimum $\mathrm{Ca}^{2+}$ load required to induce PTP opening in an entire population of mitochondria. Therefore, CRC measurement represents a suitable method to quantify and compare the potency of different PTP regulators. CRC is measured by loading mitochondria with a train of $\mathrm{Ca}^{2+}$ pulses until a rapid $\mathrm{Ca}^{2+}$ release occurs as illustrated in Figure 1a.

As shown in Figure 1b, CsA increased CRC (i.e. inhibited PTP opening) in permeabilized INS-1 cells. Interestingly, complex 1 inhibitor rotenone also inhibited PTP opening in that cell line. Accordingly, metformin also inhibited PTP opening but to a lower extent, which was expected because metformin is less potent than rotenone in complex 1 inhibition. $^{21}$

\section{CsA and metformin prevent PTP opening in intact INS-1} cells. We next checked that CsA and metformin inhibited PTP opening in intact INS-1 cells. PTP status was assessed by double channel imaging of $\mathrm{NAD}(\mathrm{P}) \mathrm{H}$ autofluorescence and mitochondrial electrical membrane potential (i.e. tetramethylrhodamine methyl ester (TMRM) fluorescence) as recently described, ${ }^{22}$ whereas $\mathrm{Ca}^{2+}$-induced PTP opening was triggered off by exposing INS-1 cells to the $\mathrm{Ca}^{2+}$ ionophore A23187. As shown in Figure 2 (left panels), A23187-induced PTP opening was followed by an increase in $\mathrm{NAD}(\mathrm{P}) \mathrm{H}$ autofluorescence both in terms of intensity and surface distribution. On the contrary, TMRM fluorescence decreased in term of intensity but not in term of surface distribution, resulting in an increase in $N A D(P) H / T M R M$ surface distribution ratio. No change in the $\mathrm{NAD}(\mathrm{P}) \mathrm{H}$ and TMRM fluorescence was observed in the absence of A23187 (data not shown). As shown in Figure 2 (middle and right panels), A23187 did not affect $\mathrm{NAD}(\mathrm{P}) \mathrm{H}$ and TMRM signals when PTP opening was prevented by either CsA or
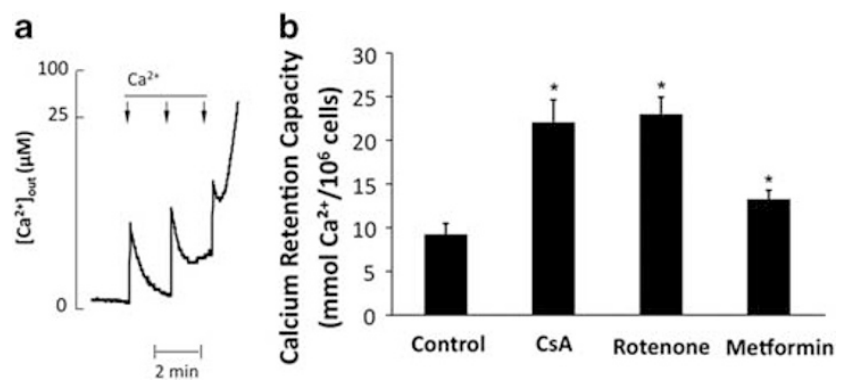

Figure 1 Effect of $\mathrm{CsA}$, rotenone and metformin on the $\mathrm{Ca}^{2+}$ retention capacity of digitonin-permeabilized INS-1 cells. (a) The incubation medium contained $250 \mathrm{mM}$ sucrose, $1 \mathrm{mM} \mathrm{Pi}, 10 \mathrm{mM}$ Tris-MOPS, $5 \mathrm{mM}$ succinate, $0.25 \mu \mathrm{M}$ Calcium Green-5N and $50 \mu \mathrm{g} / \mathrm{ml}$ digitonin. The final volume was $1 \mathrm{ml}(\mathrm{pH} 7.35)$ at $25^{\circ} \mathrm{C}$. Experiments were started by the addition of $3 \times 10^{6}$ INS-1 cells. Where indicated, $12.5 \mu \mathrm{M} \mathrm{Ca}^{2+}$ pulses were added (arrows). (b) Represents cumulative data of three different experiments performed as described in a, in control cells, in the presence of $1 \mu \mathrm{M} \mathrm{CsA}$ or $1.25 \mu \mathrm{M}$ rotenone or in cells incubated overnight in the presence of $100 \mu \mathrm{M}$ metformin. Results are mean \pm S.E.; ${ }^{*} P<0.05$ versus control, unpaired Student's t-test metformin. These data indicate that PTP opening increases the $\mathrm{NAD}(\mathrm{P}) \mathrm{H} / \mathrm{TMRM}$ surface distribution ratio in INS-1 cells, as previously shown in human endothelial cells. ${ }^{22}$

High glucose and high fructose open PTP in INS-1 cells. We next measured the $\mathrm{NAD}(\mathrm{P}) \mathrm{H}$ and TMRM fluorescence of INS-1 cells incubated in control conditions or in the presence of $30 \mathrm{mM}$ glucose or $2.5 \mathrm{mM}$ fructose for $24 \mathrm{~h}$. Note that comparisons were performed only between images acquired the same day with exactly the same microscope settings and the same load of TMRM. As shown in Figure 3, the NAD(P)H/TMRM surface distribution ratio was dramatically increased when cells were incubated in the presence of $30 \mathrm{mM}$ glucose or $2.5 \mathrm{mM}$ fructose, as compared with the control conditions. As expected, when PTP opening was prevented by either CsA or metformin, the $\mathrm{NAD}(\mathrm{P}) \mathrm{H} / \mathrm{TMRM}$ surface distribution ratio did not increase (Figure 3 ). These data indicate PTP was opened in INS-1 cells exposed to $30 \mathrm{mM}$ glucose or $2.5 \mathrm{mM}$ fructose for $24 \mathrm{~h}$.

High glucose- and high fructose-induced PTP opening leads to cell death. We finally studied the effect of $30 \mathrm{mM}$ glucose or $2.5 \mathrm{mM}$ fructose on the viability of INS-1 cells. As shown in Figure 4, $\sim 80 \%$ of the cells were alive (i.e. Annexin $\mathrm{V}-\mathrm{PI}-$ ) in control conditions. The viability of INS-1 cells was not affected by osmotic change (exposure to mannitol), whereas it was dramatically affected by $30 \mathrm{mM}$ glucose or $2.5 \mathrm{mM}$ fructose. Importantly, $30 \mathrm{mM}$ glucose-induced toxicity was hampered by CsA or metformin, whereas $2.5 \mathrm{mM}$ fructose-induced toxicity was totally prevented by CsA or metformin, indicating that PTP opening was involved in high glucose- and high fructose-induced cell death.

\section{Discussion}

In this work, we have reported that in INS-1 insulinoma cells (i) both CsA and metformin inhibited PTP opening, (ii) high glucose and high fructose led to PTP opening, (iii) PTP inhibitors hampered high glucose- and high fructose-induced cell death. Note that we have used a concentration of glucose that can be observed in clinical practice, while $30 \mathrm{mM}$ glucose or $2.5 \mathrm{mM}$ fructose are physiologically reached in the splanchnic territory during the postprandial period. ${ }^{5}$

Glucotoxicity (i.e. high glucose induced cell death) on $\beta$-cell lines or islets is now well documented. ${ }^{13,14} \mathrm{~A}$ very high concentration of fructose (i.e. $>50 \mathrm{mM}$ ) has been shown to induce cell death in hamster pancreatic $\beta$-cell-derived cell line HIT. ${ }^{13}$ Hyperglycemia or hyperfructosemia have been shown to increase ROS production. ${ }^{13,15,16}$ As pancreatic $\beta$-cells express a low level of antioxidants, ${ }^{23,24}$ this increased ROS production probably results in an oxidative stress that may affect the survival of $\beta$-cells. Supporting this scenario, several antioxidants have been proved to prevent hyperglycemiainduced cell death. ${ }^{16}$ It is well acknowledged that oxidative stress triggers PTP opening. ${ }^{6}$ Whether or not high glucose and high fructose led to PTP opening in INS-1 insulinoma cell because they increased ROS production is not demonstrated in this work, but this hypothesis is in agreement with the literature. 


\section{A23187}

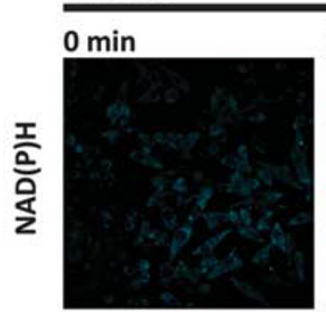
$30 \mathrm{~min}$
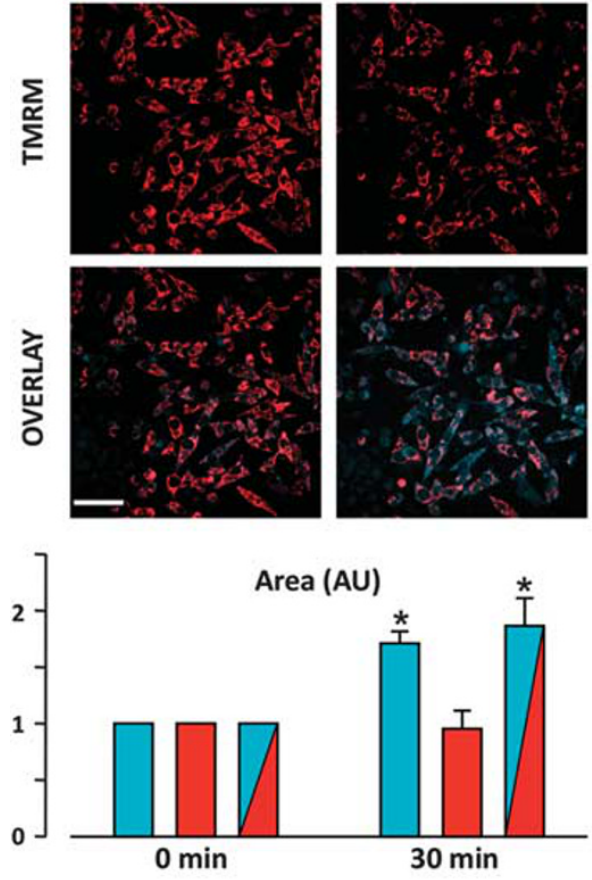

\section{$\mathrm{A} 23187+\mathrm{CsA}$}
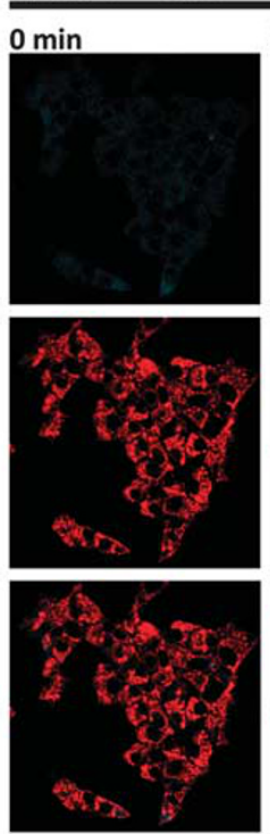

Area (AU)
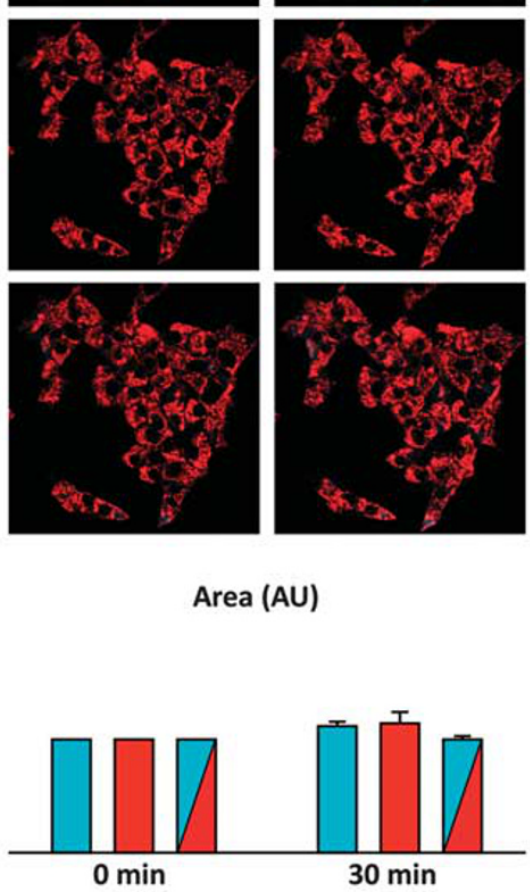

\section{A23187 + Metformin}
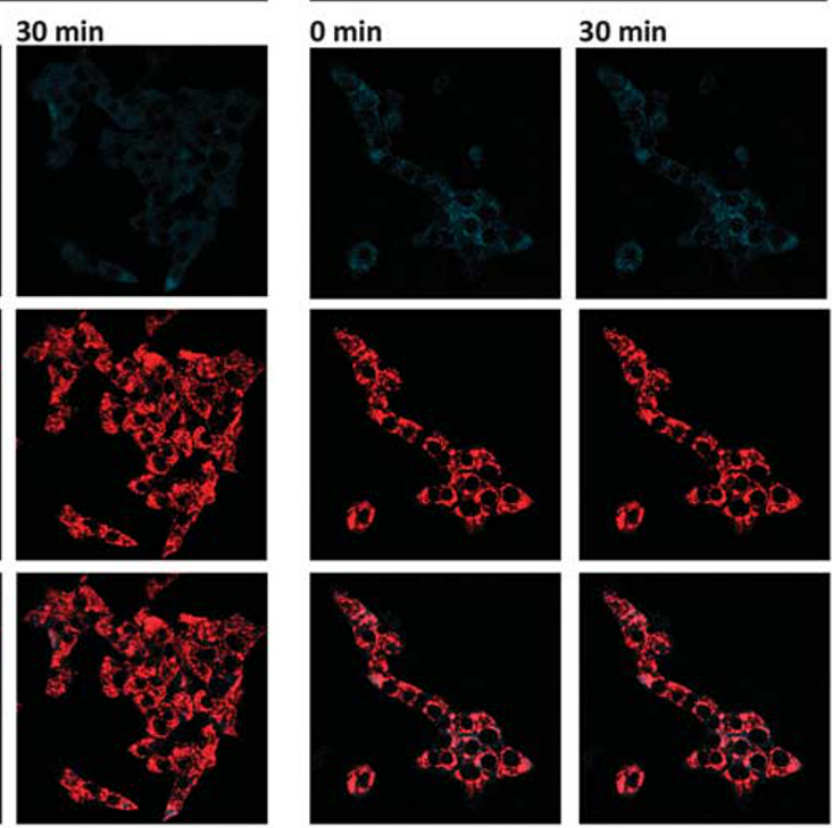

Area (AU)

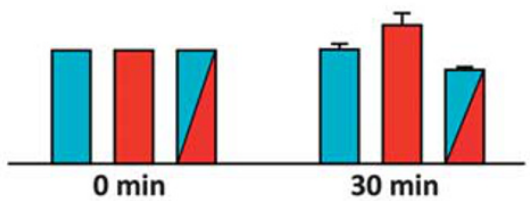

\section{NAD(P)H $\square$ TMRM $\square$ NAD(P)H/TMRM ratio}

Figure 2 Double channel imaging of $\mathrm{NAD}(\mathrm{P}) \mathrm{H}$ autofluorescence and mitochondrial electrical membrane potential. INS-1 cells incubated in the absence (control) or presence of $1 \mu \mathrm{M} \mathrm{CsA}$ or incubated overnight in the presence of $100 \mu \mathrm{M}$ metformin were loaded with $20 \mathrm{nM}$ TMRM and exposed to $150 \mathrm{nM}$ A23187. The fluorescence of $\mathrm{NAD}(\mathrm{P}) \mathrm{H}$ (blue) and TMRM (red) was imaged simultaneously every $5 \mathrm{~min}$. TMRM and NAD(P)H quantification was calculated with Volocity software using a threshold value of 3 and 50, which corresponded to the highest fluorescence outside cells for TMRM and NAD(P)H, respectively. 'Area' represents the sum of all the pixels above the threshold. For easier comparisons, areas were normalized (divided by the corresponding area before A23187 addition) before NAD(P)H/TMRM ratios were calculated. Histograms represent the results of three different experiments. Results are mean \pm S.E.; ${ }^{*} P<0.05$ versus 0 min, paired Student's $t$-test. Scale bar, $47 \mu \mathrm{m}$

Alternatively, it has been shown that high glucose concentrations modulate the balance of proapoptotic and antiapoptotic $\mathrm{Bcl}$ proteins in cultured human pancreatic islets by overexpressing Bad and Bid. ${ }^{25}$ Note, however, that among different effects, $\mathrm{Bcl}$ proteins are able to regulate PTP opening. ${ }^{26-28}$ Therefore, the observed overexpression of Bad and Bid, which may favor PTP opening, ${ }^{27,28}$ remains consistent with our results. High glucose concentration has also been shown to activate the hexosamine pathway, resulting in an impaired activation of PI 3-kinase/Akt survival pathway. ${ }^{29}$ As the activation of the survival PI 3-kinase/Akt pathway has been shown to prevent PTP opening, ${ }^{30}$ the activation of the hexosamine pathway may indirectly favor PTP opening. Therefore, high glucose concentration may (i) induce oxidative stress, (ii) modulate the Bcl proteins, and (iii) prevent the activation of the PI 3-kinase/Akt pathway. These phenomena are known to favor PTP opening and might act synergistically.
In vitro studies have suggested that sulfonylurea may induce apoptosis of pancreatic $\beta$-cell via a $\mathrm{Ca}^{2+}$-dependent process. ${ }^{31}$ Assuming that (i) sulfonylurea-induced apoptosis involves PTP opening and (ii) secondary failure to sulfonylurea is due to $\beta$-cell death, one may hypothesize that metformin would prevent or delay the risk of secondary failure to sulfonylurea. To the best of our knowledge, such a study has not been performed yet. However, it has been shown that the cumulative incidence of monotherapy failure is higher with sulfonylurea than with metformin. ${ }^{32}$ In a prospective human observational study measuring the risk of secondary failure to sulfonylurea, the same percentage of patients receiving sulfonylurea plus metformin was found in the group well controlled with oral treatment and in the group with secondary failure. ${ }^{33}$ Note however that metformin seems to have been added either after glucose rose over $300 \mathrm{mg} / \mathrm{dl}$ or after patients developed hyperglycemic symptoms, ${ }^{33}$ that is, after pancreatic $\beta$-cells apoptosis occurred. 

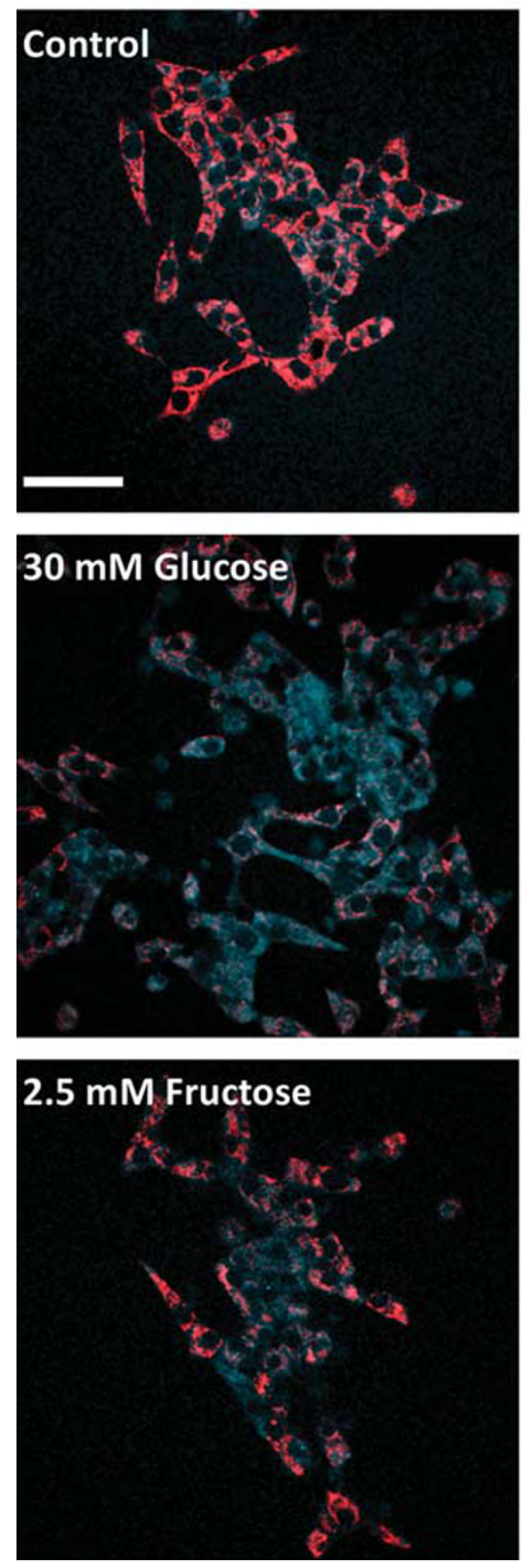

Figure 3 Effect of $30 \mathrm{mM}$ glucose or $2.5 \mathrm{mM}$ fructose on NAD(P)H autofluorescence and mitochondrial electrical membrane potential. INS-1 cells incubated in RPMI 1640 medium supplemented or not with $1 \mu \mathrm{M} \mathrm{CsA}$ for $1 \mathrm{~h}$ or $100 \mu \mathrm{M}$ metformin for $24 \mathrm{~h}$ were then incubated in complete RPMl 1640 medium supplemented or not (control) with glucose ( $30 \mathrm{mM}$, final concentration) or $2.5 \mathrm{mM}$ fructose during $24 \mathrm{~h}$. Cells were then loaded with $20 \mathrm{nM}$ TMRM for $30 \mathrm{~min}$ and the fluorescence of NAD(P)H (blue) and TMRM (red) were imaged and quantified as in Figure 2. Results are mean \pm S.E. of at least five different experiments. For each experiment, the four conditions were imaged with exactly the same microscope setting. To facilitate day to day comparisons, NAD(P)H/TMRM surface distribution ratio were normalized (i.e., in order that the NAD(P)H/TMRM surface distribution ratio in control condition was 1); ${ }^{*} P<0.05$ versus control, ${ }^{\#} P<0.05$ versus $30 \mathrm{mM}$ glucose, ${ }^{\S} P<0.05$ versus $2.5 \mathrm{mM}$ fructose, unpaired Student's $t$-test. Scale bar, $47 \mu \mathrm{m}$

By reducing the mitochondria-related toxicity of high glucose and high fructose level in $\beta$-cells, pharmacological inhibition of PTP opening may soon represents a new strategy to prevent $\beta$-cell loss during diabetes mellitus in its various aspects. Islet transplantation could represent a credible application. Although substantial progress has occurred regarding islet isolation and immunosuppression protocols, ${ }^{34}$ obstacles still compromise islet transplant success. Islets $(50-70 \%)$ are estimated to be destroyed in the immediate post transplant period, ${ }^{35}$ making $\beta$-cell apoptosis a crucial issue that prevents islet transplantation from spreading. Among several factors, this work suggests that islet exposure to high glucose and fructose levels might have a relevant role in graft death. Therefore preventing PTP opening during the islet transplant procedure (either by engraftment outside the splanchnic territory or by pharmacological inhibition of PTP opening) may enhance $\beta$ survival and improve islet transplant outcomes. Confirmatory studies with 

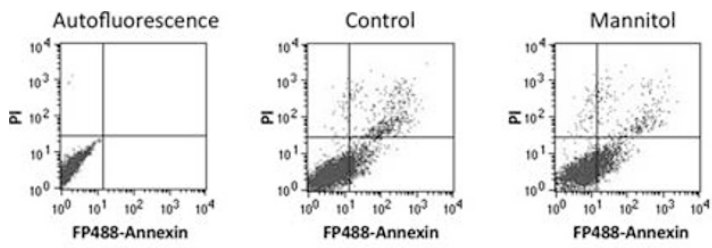

$30 \mathrm{mM}$ Glucose

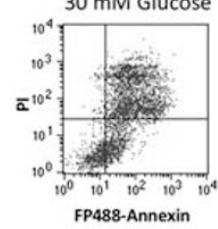

$30 \mathrm{mM}$ Glucose + CsA
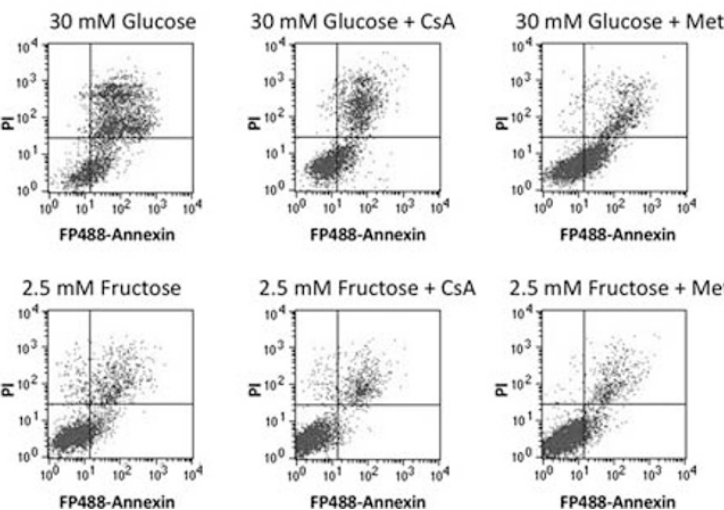

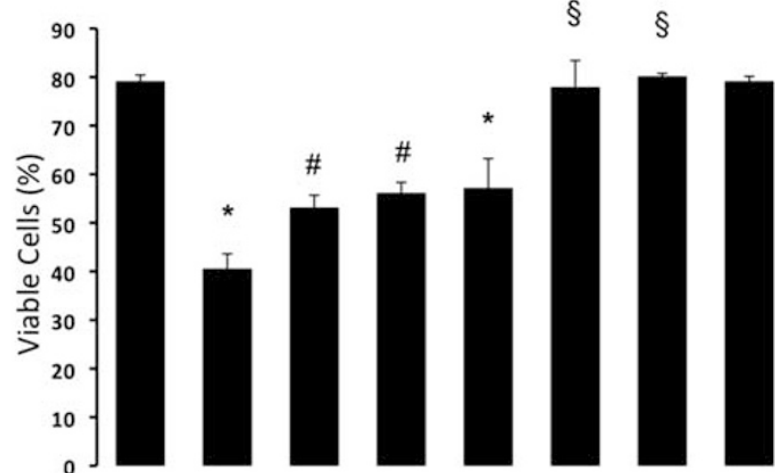

\begin{tabular}{|l|c|c|c|c|c|c|c|c|}
\hline Glucose, 30 mM & - & + & + & + & - & - & - & - \\
\hline Fructose, 2.5 mM & - & - & - & - & + & + & + & - \\
\hline CsA & - & - & + & - & - & + & - & - \\
\hline Metformin & - & - & - & + & - & - & + & - \\
\hline Mannitol & - & - & - & - & - & - & - & + \\
\hline
\end{tabular}

Figure 4 Effects of $30 \mathrm{mM}$ glucose or $2.5 \mathrm{mM}$ fructose on INS-1 viability. INS-1 cells incubated in RPMI 1640 medium supplemented or not with $1 \mu \mathrm{M}$ CsA for $1 \mathrm{~h}$ or $100 \mu \mathrm{M}$ metformin for $24 \mathrm{~h}$ were then incubated in complete RPMI 1640 medium supplemented or not (control) with mannitol (osmotic control for glucose 30 mM), glucose $(30 \mathrm{mM}$, final concentration) or $2.5 \mathrm{mM}$ fructose for $72 \mathrm{~h}$. Cell viability was assessed by double labeling as described in Materials and Methods. Histograms represent the results of three different experiments. Results are mean \pm S.E.; ${ }^{\star} P<0.05$ versus control, ${ }^{\#} P<0.05$ versus glucose $30 \mathrm{mM} 24 \mathrm{~h},{ }^{\S} P<0,05$ versus fructose $2.5 \mathrm{mM} 24 \mathrm{~h}$, unpaired Student's $t$-test

human islets are needed before proposing such a strategy in clinical trials.

\section{Materials and Methods}

Cell culture. Isolated insulinoma cell lines INS-1, a generous gift of Dr. F De Fraipont (CHU-Grenoble), were maintained in RPMl 1640 medium supplemented with $10 \mathrm{mM}$ HEPES, $10 \%$ heat-inactivated fetal calf serum, $2 \mathrm{mM}$ L-glutamine, $100 \mathrm{U} / \mathrm{ml}$ penicillin, $100 \mu \mathrm{g} / \mathrm{ml}$ streptomycin, $1 \mathrm{mM}$ sodium pyruvate and $50 \mathrm{mM}$ 2-mercaptoethanol. Cells were incubated at $37^{\circ} \mathrm{C}$ in a humidified atmosphere $(95 \%$ air, $5 \% \mathrm{CO}_{2}$ ).

Calcium retention capacity assessment. Cells were permeabilized immediately before the experiment by incubation for $2 \mathrm{~min}$ at $25^{\circ} \mathrm{C}$ in a buffer containing $10 \mathrm{mM}$ MOPS (pH 7.35), $250 \mathrm{mM}$ sucrose, $1 \mathrm{mM}$ Pi-Tris, $5 \mathrm{mM}$ succinate and $100 \mu \mathrm{g} / \mathrm{ml}$ digitonin. The calcium retention capacity was measured fluorimetrically using a PTI Quantamaster C61 spectrofluorimeter in the presence of $0.25 \mu \mathrm{M}$ Calcium Green (Molecular Probes, Illkirch, France) with excitation and emission wavelengths set at 506 and $527 \mathrm{~nm}$, respectively.

Imaging. INS-1cells set on a Lab-Tek-Chamber Slide System (Nalge Nunc International, Rochester, NY, USA) were studied by time-lapse laser confocal microscopy at $37^{\circ} \mathrm{C}$ in a humidified atmosphere $\left(95 \%\right.$ air, $\left.5 \% \mathrm{CO}_{2}\right)$ using a microscope equipped with a perfusion chamber (POC chamber, LaCom, Erbach, Germany) and an incubation system $\left(\mathrm{O}_{2}-\mathrm{CO}_{2}-{ }^{\circ} \mathrm{C}\right.$, PeCom, Erbach, Germany). Images were collected with a Leica TCS SP2 AOBS inverted laser scanning confocal microscope equipped with a Coherent 351-364 UV laser (Coherent Inc., Santa Clara, CA, USA) laser using a $63 \times$ oil immersion objective (HCX PL APO $63.0 \times 1.40$ W Corr). Laser excitation was $351-364 \mathrm{~nm}$ for NAD(P)H, and $543 \mathrm{~nm}$ for TMRM. Fluorescence emission adjusted with AOBS was $390-486 \mathrm{~nm}$ for $\mathrm{NAD}(\mathrm{P}) \mathrm{H}$, and $565-645 \mathrm{~nm}$ for TMRM. In order to allow overlay of $\mathrm{NAD}(\mathrm{P}) \mathrm{H}$ and TMRM signals, image acquisition was set with the same pinhole aperture (Airy 2.03), necessarily increased because of the low signal of $N A D(P) H$ autofluorescence. Each experiment was performed on a randomly chosen field containing 15-25 cells. Background noise of NADH autofluorescence was removed by fine filter (Kernel $3 \times 3$ ) using Volocity software. Image quantification was performed using the ImageJ (NIH images) and Volocity (Improvision, Cergy Saint Christophe, France) softwares as described in. ${ }^{22}$
Cell death induction and drug treatments. For glucose-induced cell death, cells were incubated for $72 \mathrm{~h}$ in complete RPMl 1640 medium supplemented with $19 \mathrm{mM}$ D-glucose (final concentration, $30 \mathrm{Mm}$ D-Glucose). Osmotic control was performed supplementing RPMI 1640 medium with $19 \mathrm{mM}$ mannitol. For fructoseinduced cell death, cells were exposed for $72 \mathrm{~h}$ to $2.5 \mathrm{mM} \mathrm{D}$-fructose. Before these treatments, INS-1 cells were incubated in the presence, or not, of $1 \mu \mathrm{M} \mathrm{CsA}$ for $1 \mathrm{~h}$ or $100 \mu \mathrm{M}$ metformin for $24 \mathrm{~h}$.

Quantification of cell death by flow cytometry. Apoptosis analyses were performed with a double-stain system using Annexin V (Interchim, Montluçon, France) combined with FluoProbes 488 and propidium iodide (PI) (Sigma Aldrich, Saint Quentin Fallavier, France). INS-1 cells were detached by trypsination, washed by centrifugation, and incubated with $100 \mu \mathrm{l}$ of Annexin-V buffer $1 \times(10 \mathrm{mM}$ HEPES NaOH, pH 7.4, $150 \mathrm{mM} \mathrm{NaCl}, 5 \mathrm{mM} \mathrm{KCl}, 1 \mathrm{mM} \mathrm{MgCl}_{2}$ and $1.8 \mathrm{mM} \mathrm{CaCl}_{2}$ ). Cells were then incubated for $15 \mathrm{~min}$ at room temperature in the dark in the presence of $5 \mu \mathrm{l}$ of AnnexinV-FP488. Labeled cells were transferred in a $5 \mathrm{ml}$ propylene tube containing $900 \mu \mathrm{l} \mathrm{PBS}$. A volume of $10 \mu \mathrm{l}$ from a $1 \mathrm{mg} / \mathrm{ml}$ stock solution of PI were added to the suspension and immediately analyzed.

Data acquisition ( $\sim 5000$ cells) was carried out using a FACSCAN flow cytometer (Becton Dickinson Biosciences, Le Pont de Claix, France) equipped with a $15-\mathrm{mW}$ argon ion laser tuned at $488 \mathrm{~nm}$, using the Cell Quest Pro software (Becton Dickinson Biosciences). Data were plotted as a function of fluorescence intensity on FL-1 $(530 \mathrm{~nm} / 30 \mathrm{~nm}$ band-pass filter) (Annexin V) and FL-3 channels (PI) (585-42 $\mathrm{nm}$ band pass filter). The Annexin $\mathrm{V}-/ \mathrm{PI}-$ population was regarded as normal healthy cells.

Statistics. Results are presented as means \pm S.E. The statistical significance of differences was analyzed using the Student's $t$-test. Values were considered to be different from one another when $P$-values were lower than 0.05 .

\section{Conflict of interest}

The authors declare no conflict of interest.

Acknowledgements. This work was supported by Grants from INSERM and the Ministère de l'Enseignement de la Recherche et de la Technologie (MERT). 
SL was supported by fellowships from AGIR. We also thank Christophe Cottet for the English corrections to this paper.

1. Service FJ, Nelson RL. Characteristics of glycemic stability. Diabetes Care 1980; 3: 58-62.

2. Wahjudi PN, Patterson ME, Lim S, Yee JK, Mao CS, Lee WN. Measurement of glucose and fructose in clinical samples using gas chromatography/mass spectrometry. Clin Biochem 2010; 43: 198-207.

3. Kashiwagi A, Obata T, Suzaki M, Takagi Y, Kida Y, Ogawa T et al. Increase in cardiac muscle fructose content in streptozotocin-induced diabetic rats. Metabolism 1992; 41 1041-1046.

4. Tilton RG, Chang K, Nyengaard JR, Van den Enden M, Ido Y, Williamson JR. Inhibition of sorbitol dehydrogenase. Effects on vascular and neural dysfunction in streptozocininduced diabetic rats. Diabetes 1995; 44: 234-242.

5. Bizeau ME, Pagliassotti MJ. Hepatic adaptations to sucrose and fructose. Metabolism 2005; 54: 1189-1201.

6. Zoratti M, Szabo I. The mitochondrial permeability transition. Biochim Biophys Acta 1995; 1241: 139-176.

7. Bernardi P, Krauskopf A, Basso E, Petronilli V, Blachly-Dyson E, Di Lisa F et al. The mitochondrial permeability transition from in vitro artifact to disease target. FEBS J 2006; 273: 2077-2099.

8. Desagher S, Martinou JC. Mitochondria as the central control point of apoptosis. Trends Cell Biol 2000; 10: 369-377.

9. Bernardi P. Mitochondrial transport of cations: channels, exchangers, and permeability transition. Physiol Rev 1999; 79: 1127-1155.

10. Chauvin C, De Oliveira F, Ronot X, Mousseau M, Leverve X, Fontaine E. Rotenone inhibits the mitochondrial permeability transition-induced cell death in U937 and KB cells. J Biol Chem 2001; 276: 41394-41398.

11. Detaille D, Guigas B, Chauvin C, Batandier C, Fontaine E, Wiernsperger N et al. Metformin prevents high-glucose-induced endothelial cell death through a mitochondrial permeability transition-dependent process. Diabetes 2005; 54: 2179-2187.

12. Guigas B, Detaille D, Chauvin C, Batandier C, De Oliveira F, Fontaine E et al. Metformin inhibits mitochondrial permeability transition and cell death: a pharmacological in vitro study. Biochem J 2004; 382 (Pt 3): 877-884.

13. Kaneto H, Fujii J, Myint T, Miyazawa N, Islam KN, Kawasaki $Y$ et al. Reducing sugars trigger oxidative modification and apoptosis in pancreatic beta-cells by provoking oxidative stress through the glycation reaction. Biochem J 1996; 320 (Pt 3): 855-863.

14. Kim WH, Lee JW, Suh YH, Hong SH, Choi JS, Lim JH et al. Exposure to chronic high glucose induces beta-cell apoptosis through decreased interaction of glucokinase with mitochondria: downregulation of glucokinase in pancreatic beta-cells. Diabetes 2005; $\mathbf{5 4}$ 2602-2611.

15. Robertson RP, Harmon J, Tran PO, Tanaka Y, Takahashi H. Glucose toxicity in beta-cells: type 2 diabetes, good radicals gone bad, and the glutathione connection. Diabetes 2003; 52: $581-587$.

16. Tanaka Y, Gleason CE, Tran PO, Harmon JS, Robertson RP. Prevention of glucose toxicity in HIT-T15 cells and Zucker diabetic fatty rats by antioxidants. Proc Natl Acad Sci USA 1999; 96: 10857-10862.

17. Koshkin V, Bikopoulos G, Chan CB, Wheeler MB. The characterization of mitochondrial permeability transition in clonal pancreatic beta-cells. Multiple modes and regulation. $J$ Biol Chem 2004; 279: 41368-41376.

18. Barbu A, Welsh N, Saldeen J. Cytokine-induced apoptosis and necrosis are preceded by disruption of the mitochondrial membrane potential (Deltapsi $(\mathrm{m})$ ) in pancreatic RINm5F cells: prevention by Bcl-2. Mol Cell Endocrinol 2002; 190: 75-82.

19. Marselli L, Trincavelli L, Santangelo C, Lupi R, Del Guerra S, Boggi U et al. The role of peripheral benzodiazepine receptors on the function and survival of isolated human pancreatic islets. Eur J Endocrinol 2004; 151: 207-214.
20. Fujimoto K, Chen Y, Polonsky KS, Dorn II GW. Targeting cyclophilin D and the mitochondrial permeability transition enhances beta-cell survival and prevents diabetes in Pdx1 deficiency. Proc Natl Acad Sci USA 2010; 107: 10214-10219.

21. El-Mir MY, Nogueira V, Fontaine E, Averet N, Rigoulet M, Leverve X. Dimethylbiguanide inhibits cell respiration via an indirect effect targeted on the respiratory chain complex I. J Biol Chem 2000; 275: 223-228.

22. Dumas JF, Argaud L, Cottet-Rousselle C, Vial G, Gonzalez C, Detaille D et al. Effect of transient and permanent permeability transition pore opening on $\mathrm{NAD}(\mathrm{P}) \mathrm{H}$ localization in intact cells. J Biol Chem 2009; 284: 15117-15125.

23. Moriscot C, Pattou F, Kerr-Conte J, Richard MJ, Lemarchand P, Benhamou PY Contribution of adenoviral-mediated superoxide dismutase gene transfer to the reduction in nitric oxide-induced cytotoxicity on human islets and INS-1 insulin-secreting cells. Diabetologia 2000; 43: 625-631

24. Tiedge M, Lortz S, Drinkgern J, Lenzen S. Relation between antioxidant enzyme gene expression and antioxidative defense status of insulin-producing cells. Diabetes 1997; 46: 1733-1742.

25. Federici M, Hribal M, Perego L, Ranalli M, Caradonna Z, Perego C et al. High glucose causes apoptosis in cultured human pancreatic islets of Langerhans: a potential role for regulation of specific $\mathrm{Bcl}$ family genes toward an apoptotic cell death program. Diabetes 2001; 50: 1290-1301.

26. Murphy RC, Schneider E, Kinnally KW. Overexpression of Bcl-2 suppresses the calcium activation of a mitochondrial megachannel. FEBS Lett 2001; 497: 73-76.

27. Roy SS, Madesh M, Davies E, Antonsson B, Danial N, Hajnoczky G. Bad targets the permeability transition pore independent of $\mathrm{Bax}$ or Bak to switch between $\mathrm{Ca2+-dependen}$ cell survival and death. Mol Cell 2009; 33: 377-388.

28. Zamzami N, El Hamel C, Maisse C, Brenner C, Munoz-Pinedo C, Belzacq AS et al. Bid acts on the permeability transition pore complex to induce apoptosis. Oncogene 2000; 19 6342-6350.

29. D'Alessandris $C$, Andreozzi F, Federici $M$, Cardellini M, Brunetti $A$, Ranalli $M$ et al. Increased O-glycosylation of insulin signaling proteins results in their impaired activation and enhanced susceptibility to apoptosis in pancreatic beta-cells. FASEB J 2004; 18 959-961.

30. Bopassa JC, Ferrera R, Gateau-Roesch O, Couture-Lepetit E, Ovize M. PI 3-kinase regulates the mitochondrial transition pore in controlled reperfusion and postconditioning. Cardiovasc Res 2006; 69: 178-185.

31. Efanova IB, Zaitsev SV, Zhivotovsky B, Kohler M, Efendic S, Orrenius S et al. Glucose and tolbutamide induce apoptosis in pancreatic beta-cells. A process dependent on intracellular Ca2+ concentration. J Biol Chem 1998; 273: 33501-33507.

32. Kahn SE, Haffner SM, Heise MA, Herman WH, Holman RR, Jones NP et al. Glycemic durability of rosiglitazone, metformin, or glyburide monotherapy. N Engl J Med 2006; 355 2427-2443.

33. Sesti G, Marini MA, Cardellini M, Sciacqua A, Frontoni S, Andreozzi F et al. The Arg972 variant in insulin receptor substrate-1 is associated with an increased risk of secondary failure to sulfonylurea in patients with type 2 diabetes. Diabetes Care 2004; 27: 1394-1398.

34. Merani S, Shapiro AM. Current status of pancreatic islet transplantation. Clin Sci (Lond) 2006; 110: 611-625

35. Eriksson O, Eich T, Sundin A, Tibell A, Tufveson G, Andersson $\mathrm{H}$ et al. Positron emission tomography in clinical islet transplantation. Am J Transplant 2009; 9: 2816-2824.

Cell Death and Disease is an open-access journal published by Nature Publishing Group. This work is licensed under the Creative Commons Attribution-Noncommercial-No Derivative Works 3.0 Unported License. To view a copy of this license, visit http://creativecommons.org/licenses/by-nc-nd/3.0/ 